\title{
Circumcision strategy against HIV continues to prove divisive
}

Last year, researchers published headlinegrabbing results from a series of clinical trials that found circumcised men in sub-Saharan Africa were $60 \%$ less likely to contract HIV than their uncircumcised counterparts over the course of two years (Lancet 369, 643656; 2007; Lancet 369, 657-666; 2007). The mounting evidence transformed circumcision into a promising weapon in the meager HIV prevention arsenal.

But, despite the strong data, efforts to roll out mass circumcision have met with continued resistance. In July, news agencies reported that elders from the Luo tribe, the third largest ethnic group in Kenya, had decided not to support circumcision as an HIV prevention strategy.

"Proving the efficacy [of circumcision] doesn't overcome ethical reservations or psychological and emotional doubts," says Arthur Caplan, director of the Center for Bioethics at the University of Pennsylvania in Philadelphia. "There's resistance in terms of just the symbolism of trying to do surgery on the penis."

Last month, at the biennial International AIDS Conference in Mexico City, activists and researchers failed to reach a consensus on whether male circumcision should be made available to the masses. Circumcision advocates note that cells in the foreskin seem to be highly susceptible to HIV infection, and they point to data from trials showing that the removal of this tissue reduces transmission of the virus. They also argue that reducing the prevalence of HIV in men will pay off for women in the long run. "The benefits to women are potentially very large," says Robert Bailey, an epidemiologist at the University of Illinois at Chicago who researches circumcision in Kenya.

However, according to Marge Berer, editor of the journal Reproductive Health Matters, women need protection now, not ten years down the road. "This is highly problematic," she said at the recent meeting in Mexico City. "We deserve better."

Others expressed concern that circumcision will lull men into a false sense of security, leading them to abandon safe-sex practices. Bailey published an article in June reporting that circumcision does not seem to increase risky behaviors (PLoS ONE 3, e2443; 2008), but skepticism has yet to dissipate. "If the men feel protected to the extent that this leads to a $20 \%$ decrease in condom use, the overall benefit of male circumcision in terms of HIV prevention might be nullified," says Marie de Cenival of Sidaction, a French AIDS advocacy group.
De Cenival is one of ten French activists who voiced their concerns in a letter sent in July 2007 to France's National Agency for AIDS Research, which is funding a large-scale circumcision project now underway in South Africa. She and her co-authors charged that the researchers had failed to involve local authorities, offer a complete prevention package or provide proper medical care for HIV-positive men.

"We [had] asked for a six-month delay in starting the study so that local groups and women's networks [...] could be consulted," says de Cenival. The project proceeded as scheduled, nonetheless. Because male circumcision is recommended by the World Health Organization, says principal investigator Bertran Auvert of the French research institute INSERM, delaying the project would have been unethical. He acknowledges, however, that he and his colleagues did make changes to the project on the basis of comments from both South African and French activist organizations.

Nathan Geffen of the South African AIDS activist organization Treatment Action Campaign in Cape Town criticizes de Cenival and her colleagues for trying to derail the circumcision project in South Africa. "It's the role of activist groups to scrutinize clinical trials," Geffen says. But he believes that the activists' objections stem from a deep "ideological opposition to circumcision" rather than specific issues with the project.

Yet, regardless of the activists' concerns and opposition from tribes such as the Luo, many men in sub-Saharan Africa seem eager to undergo circumcision to cut the risk of HIV infection. "Men are lining up," Bailey says. "We can't meet the demand."

Cassandra Willyard, Washington, DC

\section{Stem cells promise to dish on diseases}

New advances in stem cell research promise to make it possible to watch the development of various diseases unfold in a Petri dish. Experts have now created stem cell lines affected by ten genetic disorders, which they intend to share with scientists hoping to understand and develop new treatments for these vexing ailments.

George Daley of the Harvard Stem Cell Institute ( $\mathrm{HSCl}$ ) in Cambridge, Massachusetts and his colleagues took skin and bone marrow cells from individuals with disorders such as Parkinson's disease and juvenile diabetes and infected the cells with a cocktail of specially engineered viruses. This prompted the cells to revert to a naive state, turning them into what's known as induced pluripotent stem (iPS) cells, which can develop into almost any type of tissue in the body (Cell, doi:10.1016/j. cell.2008.07.041; 2008). Observing the behavior of these cells might reveal what goes awry with human cells in various diseases and may offer a promising alternative to animal models of human disease. "The strategy would be to compare the lines from normal individuals with the tissue formation of disease patients," Daley says.

Daley's team is transferring the stem cell lines to an $\mathrm{HSCl}$ iPS cell laboratory at the Massachusetts General Hospital

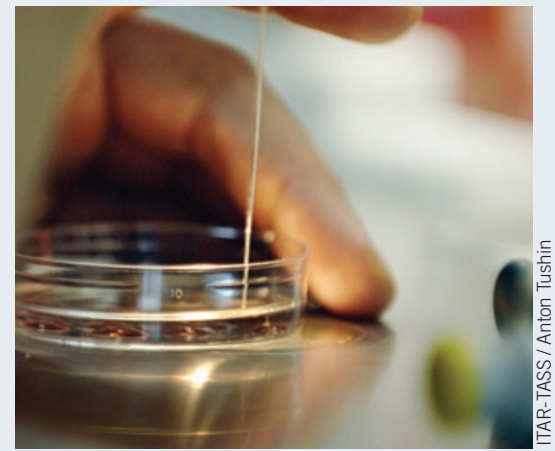

Watch this: Cell patterns might hold clues

in Boston, and $\mathrm{HSCl}$ will oversee the allotment of the new cell lines to outside scientists. "We are going to try to keep up with the requests," says Daley, noting that the cells are "finicky," and scientists wishing to use them should have cell-culturing expertise.

"This work confirms the value and robustness of the iPS technique," says Jonathan Slack, who directs the University of Minnesota's Stem Cell Institute in Minneapolis. The viruses used to revert the cells to a naive state might cause their growth to go haywire. But Slack adds that "this is obviously less of a problem if the cells are destined for research use, as [they are] here, than if they were destined for therapeutic use."

Coco Ballantyne, New York 